\title{
E-MARKETPLACE MEDIA PENGEMBANGAN PROMOSI USAHA MIKRO KECIL DAN MENENGAH DINAS KOPERASI UMKM KOTA PEKANBARU
}

\author{
${ }^{1}$ Tengku Khairil Ahsyar, ${ }^{2}$ Syaifullah, ${ }^{3}$ Ardiansyah \\ ${ }^{1,2,3}$ Program Studi Sistem Informasi, Fakultas Sains dan Teknologi \\ Universitas Islam Negeri Sultan Syarif Kasim Riau \\ Jl. HR Soebrantas KM.18 Panam Pekanbaru - Riau \\ Email: ${ }^{1}$ tengkukhairil@uin-suska.ac.id, ${ }^{2}$ syaifullah@uin-suska.ac.id, \\ 3aardi25@uin-suska.ac.id
}

\begin{abstract}
ABSTRAK
Usaha Mikro Kecil dan Menengah atau yang lebih dikenal dengan istilah UMKM adalah suatu badan usaha yang tidak memiliki kaitan dengan perusahaan tertentu. UMKM berkembang dengan sangat pesat dan memiliki peranan penting bagi perekenomian. Kendala utama yang di hadapi pelaku UMKM adalah sulitnya melakukan promosi produk secara luas dan hal ini terjadi hampir diseluruh UMKM termasuk UMKM kota Pekanbaru. Mengatasi hal ini, Berbagai strategi telah diterapkan oleh pihak dinas Koperasi dan UMKM kota Pekanbaru diantaranya: mengadakan pameran keberbagai daerah, melakukan kerjasama dengan pihak ketiga dan memberikan layanan konsultasi bisnis. Namun, strategi-startegi ini di nilai kurang efektif karena masih banyak terdapat kelemahan seperti besarnya biaya yang dibutuhkan, terbatasnya UMKM yang bisa ikut serta, singkatnya waktu serta kecilnya ruang lingkup promosi. Tujuan penelitian ini melakukan pengembangan sistem e-Marketplace berbasis web sebagai media promosi produk UMKM. Dalam pengembangan sistem ini menggunakan metode waterfall dan menggunakan Object Oriented Analysis Design sebagai metode analisis dan disain sistem. Sedangkan untuk analisis biaya dan manfaat menggunakan metode payback periode dan Return on Investment (ROI). Hasil dari penelitian ini berupa sistem e-Marketplace berbasis web. Hasil uji yang dilakukan terhadap fitur-fitur yang terdapat pada $e$-Marketplace yang telah dibuat berjalan $100 \%$ pada beberapa web browser populer. Sedangkan hasil pengujian dengan menggunakan User Acceptance Test terkait tingkat penerimaan user serta fitur-fitur sistem adalah $100 \%$. Berdasarkan hasil pengujian sistem yang telah dilakukan dapat diambil kesimpulan bahwa sistem e-Marketplace yang di buat dapat berjalan dengan baik dan tingkat penerimaan sistem juga sangat baik. Sehingga sistem dapat mempermudah pihak pelaku UMKM dalam mempromosikan produk mereka secara luas.
\end{abstract}

Kata kunci: e-Marketplace, UMKM, Payback Periode, ROI, User Aceptence Test (UAT)

\section{A. PENDAHULUAN}

Usaha Mikro Kecil dan Menengah (UMKM) merupakan jenis usaha yang di dirikan oleh perorangan ataupun suatu badan usaha yang tidak memiliki kaitan dengan perusahaan tertentu dan sesuai dengan kategori yang telah ditetapkan. Adapun kategori yang di maksud berupa jumlah hasil penjualan tahunan. Untuk usaha mikro maksimal penjualan sebanyak Rp 300.000.000,00 (tiga ratus juta rupiah), kemudian untuk usaha kecil maksimal penjualan sebanyak Rp 2.500.000.000,00 (dua milyar lima ratus juta rupiah) dan terakhir untuk usaha menengah maksimal penjualan sebanyak Rp 50.000.000.000,00 (lima puluh milyar rupiah) [1]. UMKM sendiri merupakan jenis bisnis yang bergerak pada berbagai bidang usaha yang menyentuh kepentingan masyarakat. Hal ini membuat UMKM terus berkembang dengan sangat pesat serta memiliki peran yang sangat penting bagi sektor perekonomian di Indonesia.

Pada tahn 2018, UMKM memiliki proporsi sebesar 99,99\% dari total keseluruhan pelaku usaha yang ada di Indonesia atau sebanyak 56,54 juta unit. UMKM juga memberikan kontribusi terhadap produk domestik bruto sebanyak $59.08 \%$ (Rp 4.869,57 trilliun) dengan laju pertumbuhan sebesar $6,4 \%$ pertahunnya. Tak hanya itu saja UMKM juga menyumbang terhadap volume ekspor mencapai $14.06 \%$ (Rp 166,63 trilliun) dan mampu menyerap banyak tenaga kerja yang persentasenya mencapai 97\% [2].

Walaupun UMKM memiliki jumlah yang banyak dan memiliki kontribusi yang besar, namun masih terdapat beberapa tantangan dan masalah yang di hadapi oleh UMKM baik itu secara internal maupun eksternal. Secara internal, keberadaan UMKM lebih banyak menghadapi berbagai keterbatasan terkait modal, teknik produksi, pangsa pasar, manajemen dan teknologi, lemah dalam pengambilan keputusan dan pengawasan keuangan serta rendahnya daya saing. Sedangkan, secara eksternal lebih banyak menghadapi masalah seperti: persoalan perijinan, bahan baku, lokasi pemasaran, sulitnya memperoleh kredit bank, iklim usaha yang kurang kondusif, kepedulian masyarakat, dan kurang pembinaan [3].

Kendala ini terjadi hampir pada seluruh UMKM di Indonesia termasuk UMKM yang ada di 
kota Pekanbaru. Namun, salah satu permasalahan utama bagi UMKM kota Pekanbaru saat ini lebih kepada sulitnya pelaku usaha dalam melakukan pemasaran dan promosi produk mereka secara luas. Sementara itu, jumlah UMKM kota Pekanbaru terus bertambah setiap tahunnya.

Menyikapi hal ini berbagai upaya terus dilakukan oleh pihak dinas koperasi UMKM kota Pekanbaru. Wujud nyata dari upaya pihak dinas ini ditetapkanlah strategi-strategi berikut guna memperluas promosi. Strategi pertama adalah mengadakan pameran baik itu di luar kota maupun di dalam kota. Kedua, melakukan kerjasama dengan pihak ketiga guna menyediakan tempat bagi UMKM kota Pekanbaru. Terakhir, pihak dinas memberikan dukungan layanan berupa Klinik Konsultasi Bisnis (KKB) guna memudahkan para pelaku usaha untuk mengatasi permasalahan yang ada pada UMKM mereka.

Namun, strategi-strategi yang telah dilakukan ini dinilai masih terdapat kelemahan dalam pelaksanaanya. Terkait pameran misalnya, permasalahan utama adalah dana. Dalam melaksanakan pameran diperlukan dana yang cukup besar mencapai Rp 100.000.000,00 (seratus ratus juta rupiah) per sekali pameran. Besarnya dana ini membuat pelaksanaan pameran tidak bisa dilaksanakan secara rutin. Selanjutnya, UMKM yang dapat ikut serta juga terbatas. Untuk pameran diluar daerah, UMKM yang bisa ikut serta hanya 6 sampai 10 UMKM saja. Ini mengakibatkan banyak UMKM yang tidak dapat dipromosikan secara luas. Ditambah lagi, jika dilihat dari sisi pengunjung, strategi ini hanya mampu mendatangkan pengujung dari dalam daerah tempat dimana pameran ini dilaksanakan. Faktor jarak yang jauh antara satu daerah ke daerah lain menjadi kendala utama bagi pengunjung untuk datang. Hal ini tentunya membuat pameran harus dilakukan ke berbagai daerah jika ingin dikenal luas. Tentunya ini akan memakan waktu yang sangat lama. Berbicara waktu, pameran biasanya maksimal dilaksanakan hanya 7 hari. Singkatnya waktu pameran ini juga mengakibatkan promosi tidak bisa dilakukan secara maksimal.

Begitu pula dengan kerjasama dengan pihak ketiga, terbatasnya tempat yang disediakan oleh pihak ketiga menjadi kendala sehingga tidak banyak UMKM yang dapat mendirikan toko disana. Selain itu, adanya biaya berupa biaya sewa tempat ataupun biaya listrik. Ini juga cukup memberatkan bagi pihak pelaku usaha yang mendirikan toko. Hal ini dikarenakan kebanyakan pelaku usaha tergolong usaha mikro dan kecil yang memiliki keterbatasan akan modal.

Sedangkan untuk layanan $\mathrm{KKB}$, layanan ini berjalan kurang maksimal dikarenakan masih banyaknya pelaku usaha atau masyarakat yang malu atau enggan untuk berkonsultasi langsung kepada pihak dinas. Ditambah lagi jauhnya jarak yang harus ditempuh untuk sekedar melakukan konsultasi ini juga mengakibatkan mereka menjadi enggan untuk datang ke kantor dinas.

Untuk mengatasi permasalahan yang telah dipaparkan di atas, e-Marketplace dapat dijadikan sebagai solusi dalam membantu dinas Koperasi UMKM dalam mempromosikan produk UMKM kota Pekanbaru. e-Marketplace memanfaatkan media digital berupa internet untuk menciptakan suatu lingkungan atau tempat yang mewadahi para penjual dan pembeli untuk melakukan prosesproses bisnis mulai dari pemasaran produk, penawaran produk, mengembangkan komunikasi antara penjual dan pembeli sehingga tercapai kepuasan terhadap keduanya [4].

\section{B. LANDASAN TEORI}

\section{B.1. e-Marketplace}

e-Marketplace adalah segala usaha yang dilakukan untuk melakukan pemasaran suatu produk atau jasa melalui media internet atau jaringan world wide web. Sedangkan place sendiri dalam kamus bahasa Inggris artinya adalah tempat. Jadi, pengertian dari e-Marketplace adalah tempat atau wadah untuk melakukan pemasaran produk atau jasa melalui atau menggunakan media internet [5].

\section{B.2. Promosi}

Promosi adalah bagian dari bauran pemasaran yang besar perannya. Promosi merupakan kegiatankegiatan yang secara aktif dilakukan perusahaan untuk mendorong konsumen membeli produk yang ditawarkan. Promosi juga dikatakan sebagai proses berlanjut karena dapat menimbulkan rangkaian kegiatan perusahaan yang selanjutnya. Karena itu promosi dipandang sebagai arus informasi atau persuasi satu arah yang dibuat untuk mengarahkan seseorang atau organisasi agar melakukan pertukaran dalam pemasaran. Kegiatan dalam promosi ini pada umumnya adalah periklanan, personal selling, promosi penjualan, pemasaran langsung, serta hubungan masyarakat dan publisitas [5].

\section{B.3. Payback Period dan Return on Investment}

Analisis biaya dan manfaat adalah suatu cara yang digunakan untuk menentukan suatu sistem informasi layak atau tidak untuk diterapkan. Dalam proses analisis suatu investasi terdapat dua aliran kas, yaitu aliran kas keluar (cash outflow) dan aliran kas masuk (cash inflow). Aliran kas keluar terjadi karena pengeluaran-pengeluaran uang untuk biaya investasi. Aliran kas masuk terjadi dari manfaat yang dihasilkan dari investasi. Terdapat beberapa metode dalam melakukan analisis biaya dan manfaat, dalam penelitian ini menggunakan dua metode yakni metode periode pengembalian (payback period) dan metode pengembalian investasi (return on investment) [6]. Penelitian 
sebelumnya pernah menerapkan metode Payback Period dan Return on Investment pada sistem dibidang akademik dan dapat mengetahui berapa lama periode pengembalian dan pengembalian investasi untuk sistem tersebut [8].

1. Rumus Metode Payback Periode PaybackPeriod

$$
=\frac{\text { NilaiInvestasiawal }}{\text { Proceed }}
$$

2. Rumus Metode Return Of Investment (ROI)

$$
R O I=\frac{\text { TotalManfaat }- \text { TotalBiaya }}{\text { TotalBiaya }} X 100
$$

\section{B.4. User Acceptance Test (UAT)}

Sedangkan pengujian User Acceptance Test adalah proses pengujian oleh user dan menghasilkan dokumen untuk dijadikan bukti bahwa aplikasi yang dikembangkan dapat diterima user dan hasil pengujiannya dianggap memenuhi kebutuhan pengguna [7]. Metode UAT ini nantinya akan digunakan pada tahap pengujian sistem untuk melihat apakah pengguna sistem e-Marketplace dapat menerima sistem yang telah dibangun. Berikut ini merupakan rumus perhitungan dari pengujian dengan menggunakan metode User Acceptance Testing.

Persentase keberhasilan $=$

$\frac{\text { Jawaban berhasil }}{\text { Jumlah pertanyaan }} \times 100$

\section{METODOLOGI}

Agar penelitian ini dapat diselesaikan sesuai dengan target yang akan dicapai, terdapat beberapa tahapan dalam penelitian ini yang diadopsi dari tahapan-tahapan yang ada pada metode Waterfall, yakni Perencanaan, Pengumpulan Data, Analisa dan Perancangan, Implementasi, serta Pengujian sistem. Berikut penjelasan dari masing-masing tahapan:

\section{C.1. Perencanaan}

Pada tahap ini melakukan perencanaan penelitian agar proses penelitian yang dijalankan berjalan dengan lancar. Adapun yang direncanakan dalam pnelitian ini adalah merumuskan permasalahan, menentukan pustaka-pustaka terkait, dan penentuan tujuan penelitian. Tujuan penelitian ini adalah membangun sistem $e$-Marketplace yang dapat membantu para UMKM berdasarkan permasalahan-permasalahan yang ditemui.

\section{C.2. Pengumpulan Data}

Pada tahap ini melakukan observasi langsung terhadap objek-objek terkait yang diteliti, melakukan wawancara terhadap pelaku-pelaku yang terlibat didalam penelitian ini, dan melakukan studi pustaka sebagai data sekunder untuk memperkuat penelitian ini. Pengambilan data sampel untuk fungsionalitas sistem juga dilakukan pada tahap ini seperti data-data member UMKM.

\section{C.3. Analisa dan Perancangan}

Pada tahap ini melakukan analisis permasalahan dan sistem yang sedang berjalan, menganalisis biaya dan manfaat, menganalisis kebutuhan sistem usulan, dan melakukan perancangan database dan antarmuka sistem. Metode yang digunakan pada penelitian ini untuk menganalisis dan melakukan perancangan sistem menggunakan Object Oriented Analisys and Design System (OOAD).

\section{C.4. Implementasi}

Pada tahap ini melakukan pengodingan berdasarkan dari hasil analisis sistem dan sesuai dengan perancangan yang telah dibuat pada tahap perancangan sistem. Sistem yang dibangun adalah sistem $e$-Marketplace sebagai wadah bagi UMKM berdasarkan permasalahan-permasalahan yang ingin diselesaikan.

\section{C.5. Pengujian Sistem}

Pada tahap ini melakukan pengujian sistem dengan menggunakan metode UAT. Metode ini digunakan untuk melihat apakah sistem dapat diterima dengan baik oleh calon pengguna sistem. Selain dari itu, pengujian sebelumnya dilakukan terhadap beberapa web browser populer yang nantinya akan digunakan oleh pengguna.

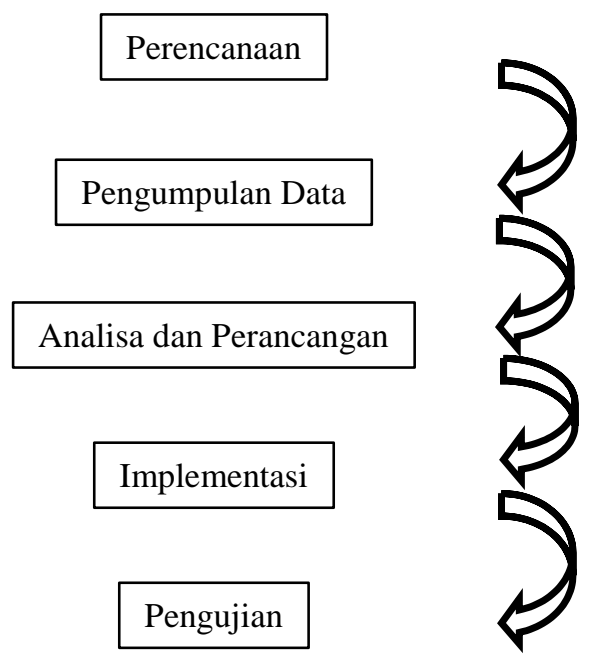

Gambar 1. Tahapan Penelitian

Untuk melihat tahapan-tahapan penelitian ini dalam bentuk bagan sesuai dengan urutan awal sampai akhir penelitian dapat dilihat pada Gambar 1. 


\section{ANALISA DAN PERANCANGAN \\ D.1. Analisa Masalah}

Dari hasil identifikasi maka diperoleh beberapa kekurangan yang ada pada sistem yang sedang berjalan, diantaranya (1) Kegiatan pameran tidak bisa diadakan secara terus menerus; (2) Waktu pelaksanaan kegiatan pameran terbatas; (3) UMKM yang dapat di tampung pada kegiatan pameran terbatas; (4) Jangkauan promosi menggunakan pameran tidak terlalu luas; (5) Pada kegiatan pameran tidak semua kategori UMKM bisa ikut serta; (6) Pada kerjasama pihak ketiga tempat yang disediakan terbatas; (7) Penyewaan tempat pada pihak ketiga hanya bisa dilakukan oleh UMKM yang telah memiliki modal yang cukup; dan (8) KKB masih kurang diminati oleh pelaku usaha.

Dari hasil identifikasi masalah yang telah dilakukan, penyebab masalah tersebut diketahui sebagai berikut: (1) Besarnya biaya yang dibutuhkan untuk pengadaan kegiatan pameran menyebabkan pameran tidak bisa dilaksanakan secara berkala; (2) Terbatasnya dana yang dimiliki oleh dinas dan besarnya biaya untuk pengadaan kegiatan pameran mengakibatkan lamanya waktu pelaksanaan pameran yang hanya bisa diadakan kurang lebih 3 sampai dengan 7 hari; (3) Banyaknya jumlah UMKM di kota Pekanbaru yang mencapai ribuan tidak dapat ditampung secara keseluruhan dalam sebuah acara pameran; (4) Pemasaran melalui pameran mengharuskan masyarakat untuk datang langsung ke lokasi diadakannya pameran, sehingga masyarakat yang berlokasi jauh dipastikan tidak akan dapat melihat pameran; (5) Kegiatan pameran biasanya lebih banyak menampilkan UMKM yang berkategori kerajinan dan makanan khas sehingga UMKM dengan kategori seperti jasa, persewaan dan lainnya jarang mendapatkan tempat di pameran; (6) Lokasi yang dimiliki oleh pihak ketiga yang bekerjasama dengan pihak koperasi tidak terlalu luas. Sehingga hanya menampung beberapa UMKM saja; (7) Tempat yang disediakan oleh pihak ketiga biasanya pelaku usaha di haruskan membayar uang sewa ataupun uang lampu. Hal ini tentunya memberatkan untuk UMKM yang baru atau yang memiliki modal terbatas. Mereka jadi tidak memiliki tempat mempromosikan produk atau usaha mereka; dan (8) Klinik konsultasi bisnis masih menggunakan sistem face to face dalam proses konsultasinya sehingga pelaku usaha yang ingin melakukan konsultasi harus datang langsung guna melakukan konsultasi atau bertanya seputar UMKM. Kesibukan yang di miliki pelaku usaha, dan jarak yang di tempuh mengakibatkan banyak pelaku usaha yang enggan untuk melakukan konsultasi.

\section{D.2. Analisa Biaya dan Manfaat D.2.1. Payback Periode}

Hasil dari perhitungan metode payback periode untuk sistem $e$-Marketplace yang dibangun dapat dilihat pada perhitungan nilai investasi di bawah ini:

$\begin{array}{ll}\text { Nilai Investasi } & =\operatorname{Rp} 88.450 .000 \\ \text { Proceed tahun 1 } & =\underline{\operatorname{Rp} 45.585 .000}- \\ \text { Sisa Investasi tahun 2 } & =\operatorname{Rp} 42.865 .000\end{array}$

Sisa investasi tahun ke 2 tertutup oleh proceed tahun ke 2 sebagian dari Rp 60.035.000 yaitu Rp 42.515.000 / Rp 60.035.000 = 0,708 bagian. Hal ini dapat diketahui dari perhitungan Payback Period investasi tersebut bahwa keuntungan/manfaat yang akan di rasakan setelah menerapkan sistem selama 1 tahun 7 bulan.

\section{D.2.2. Return of Investment (ROI)}

Metode ROI digunakan untuk mengukur persentase manfaat yang dihasilkan proyek dibanding dengan biaya yang di keluarkan. Hasil perhitungan ROI berdasarkan rumus ROI dapat dilihat pada perhitungan di bawah ini:

$$
\frac{\operatorname{Rp} 414.905 .000-\operatorname{Rp} 308.800 .000}{\operatorname{Rp} 308.800 .000} \times 100 \%
$$

$\mathrm{ROI}=0.343 \times 100 \%$

$\mathrm{ROI}=34.3 \%$

Suatu proyek investasi yang memiliki nilai ROI lebih dari 0 adalah proyek yang dapat diterima. Dari hasil perhitungan yang telah dilakukan, diperoleh bahwa nilai ROI untuk penerapan e-Marketplace adalah 0,343 atau 34,3\% dapat pula disimpulkan bahwa penerapan $e$ Marketplace ini dapat diterima. Hal ini dikarenakan sistem dapat memberikan keuntungan sebesar $34,3 \%$ dari biaya investasinya.

\section{D.3. Analisa dan Perancangan Sistem}

Sebelum membangun sistem, mengidentifikasi pengguna merupakan keharusan bagi setiap pengembang sistem. Sistem yang dirancang pada $e$-Marketplace ini memiliki 4 aktor (pengguna), yaitu Admin Utama, Admin KKB Online, Member dan Masyarakat. Untuk melihat aktor-aktor yang terlibat pada sistem $e$-Marketplace yang dibangun beserta kasus pengguna (use case) dapat dilihat pada Gambar 2, Gambar 3, Gambar 4, dan Gambar 5.

Pada use case diagram untuk aktor Masyarakat (Gambar 2) dapat dilihat bahwa aktor tersebut memiliki 5 use case yang secara umum terdiri dari iklan, lokasi usaha, bantuan dan info, serta komunikasi KKB secara online. Sedangkan pada use case diagram untuk aktor Admin Utama terdapat 7 use case yang secara umum terdiri dari pengelolaan data member, petugas, iklan, UMKM, info web, info admin, serta penyajian informasi dalam bentuk grafik. Untuk use case diagram 
Admin KKB Online hanya terdapat 2 use case yang berhubungan dengan kelola anggota dan komunikasi dalam bentuk chating. Terakhir adalah use case diagram Member. Pada use case diagram ini, terdiri dari 8 use case yang secara umum terdiri dari daftar member, kelola akun, iklan, profil usaha, autentikasi (password), dan komunikasi dalam bentuk chating.

Sedangkan untuk melihat proses yang berkaitan dengan aktor sistem secara sekuensial dapat dilihat dari salah satu sequence diagram sistem seperti yang ada pada Gambar 6. Gambar 6 merupakan squence diagram untuk kelola data UMKM pada sistem admin panel $e$-Marketplace.

Activity diagram sistem $e$-Marketplace pada penelitian ini dapat dilihat pada Gambar 7 yang merupakan salah satu Activity Diagram untuk kelola data UMKM. Sedangkan visualisasi database terkait sistem yang dibangun divisualisasikan lewat class diagram seperti yang ada pada Gambar 8. Item-item yang terdapat pada class diagram ini menjadi rujukan dalam merancang database sistem $e$-Marketplace.

Sedangkan untuk melihat salah satu tampilan perancangan antarmuka e-Marketplace dapat dilihat pada Gambar 9 yang keterangan dari disain antarmuka tersebut dapat dilihat lebih rinci pada Tabel 1 Perancangan dasboard admin panel.

Tabel 1. Perancangan Halaman Dashboard Admin Panel $e$-Marketplace

\begin{tabular}{|l|l|ll|}
\hline No & Nama & & \multicolumn{1}{|c|}{ Keterangan } \\
\hline 1. & Navbar & a. Background color \#e53935. \\
& & b. Ukuran width 100\%, min-height \\
& & c0px. \\
& & c. border none. \\
& & d. position fixed. \\
& & e. Jarak margin-bottom 40px. \\
\hline 2. & Nama & a. Font Color \#ffff. \\
& sistem & b. Font Size 18px. \\
& & c. Jenis font Roboto, sans-serif. \\
& & d. Ukuran Height 50px. \\
& & e. Jarak padding 15px 15px, margin \\
& & f. left -15px. \\
\hline
\end{tabular}

\begin{tabular}{|c|c|c|}
\hline 3. & $\begin{array}{l}\text { Icon profil } \\
\text { dan logout }\end{array}$ & $\begin{array}{l}\text { a. } \begin{array}{l}\text { Berfungsi untuk menampilkan } \\
\text { halaman profil dan keluar dari } \\
\text { sistem. }\end{array} \\
\text { b. Menggunakan material icon } \\
\text { selengkapnya dapat dilihat pada } \\
\text { bab 2.13.14. } \\
\text { c. Ukuran icon 24px. }\end{array}$ \\
\hline 4. & $\begin{array}{l}\text { Layout } \\
\text { admin info }\end{array}$ & $\begin{array}{l}\text { a. Ukuran width } 300 \mathrm{px} \text {, height } \\
\text { 135px. } \\
\text { b. Background image. } \\
\text { c. Jarak padding } 13 \mathrm{px} 15 \mathrm{px} 12 \mathrm{px} \\
\text { 15px. } \\
\text { d. Position relative. } \\
\text { e. Border bottom } 1 \mathrm{px} \text { solid } \# \mathrm{e} 9 \mathrm{e} 9 \mathrm{e} 9 .\end{array}$ \\
\hline 5. & $\begin{array}{l}\text { Foto profil } \\
\text { admin }\end{array}$ & $\begin{array}{l}\text { a. Ukuran width 50px height 50px. } \\
\text { b. Border radius 50\%. }\end{array}$ \\
\hline 6. & $\begin{array}{l}\text { Nama } \\
\text { admin dan } \\
\text { status }\end{array}$ & $\begin{array}{ll}\text { a. } & \text { Font size } 14 \mathrm{px} . \\
\text { b. } & \text { Jarak top 25px. } \\
\text { c. } & \text { Font color \#ffff. } \\
\text { d. } & \text { Ukuran max width 200px. }\end{array}$ \\
\hline 7. & $\begin{array}{l}\text { Menu } \\
\text { utama }\end{array}$ & $\begin{array}{l}\text { a. Ukuran width 300px, height } \\
\text { 357px. } \\
\text { b. Position Relative. } \\
\text { c. Font Color \#747474. } \\
\text { d. Icon Color \#747474. } \\
\text { e. Font size } 14 p x . \\
\text { f. Jenis font Roboto, sans-serif. } \\
\text { g. Font color active menu \#e53935. }\end{array}$ \\
\hline 8. & Copyright & $\begin{array}{ll}\text { a. } & \text { Font size } 13 \mathrm{px} . \\
\text { b. } & \text { Jenis font Roboto, sans-serif. } \\
\text { c. } & \text { Font color black. } \\
\text { d. } & \text { Link color \#e } 53935 . \\
\text { e. } & \text { Background color \#ffff. } \\
\text { f. } & \text { Ukuran width } 100 \% \text {. } \\
\text { g. } & \text { Jarak padding } 15 \mathrm{px} . \\
\end{array}$ \\
\hline 9. & $\begin{array}{l}\text { Info total } \\
\text { data }\end{array}$ & $\begin{array}{ll}\text { a. } & \text { Menampilkan data total dari } \\
\text { jumlah UMKM, member,iklan } \\
\text { dan loker. } \\
\text { b. Ukuran width } 25 \% \text { height } 80 \mathrm{px} . \\
\text { c. Jarak padding right } 15 \mathrm{px} \text {, padding } \\
\text { left } 15 \mathrm{px}, \text { margin bottom } 30 \mathrm{px}, \\
\text { margin top } 11 \mathrm{px} . \\
\text { d. Font and icon color \#fff. } \\
\text { e. Font size } 13 \mathrm{px} . \\
\text { f. }\end{array}$ \\
\hline 10 & Grafik & $\begin{array}{l}\text { a. Menampilkan Grafik UMKM dan } \\
\text { grafik member. } \\
\text { b. Plugin untuk grafik menggunakan } \\
\text { chart.js keterangan lengkap dapat } \\
\text { di lihat pada sub bab 2.13.8. } \\
\text { c. Ukuran width } 50 \% \text { height } 264 \mathrm{px} \text {. } \\
\text { d. Ukuran text header 18px. } \\
\text { e. Font color \#111. } \\
\text { f. Jarak margin botom 30px. }\end{array}$ \\
\hline
\end{tabular}


Jurnal Ilmiah Rekayasa dan Manajemen Sistem Informasi, Vol. 6, No. 1, Februari 2020, Hal. 43-54 e-ISSN 2502-8995 p-ISSN 2460-8181

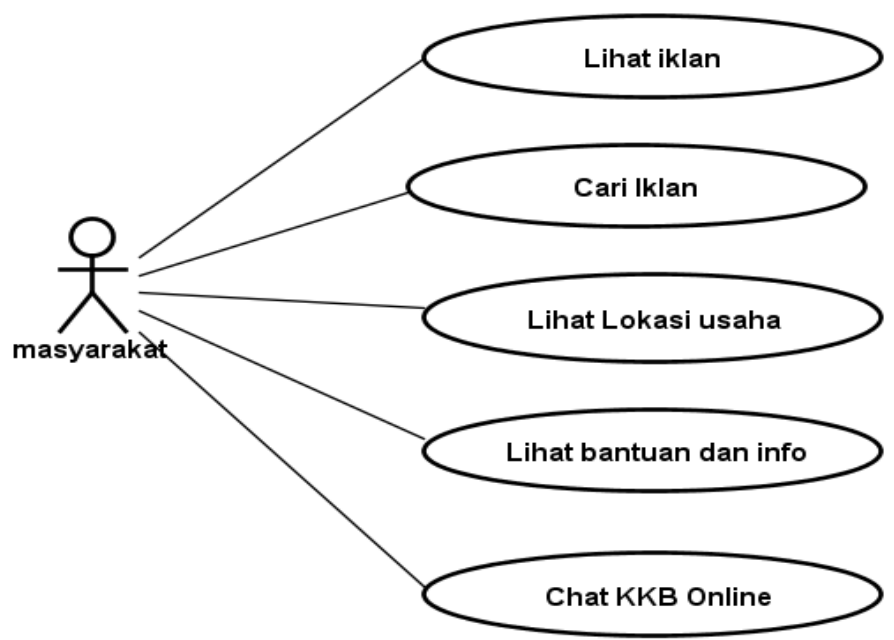

Gambar 2. Use case diagram Masyarakat

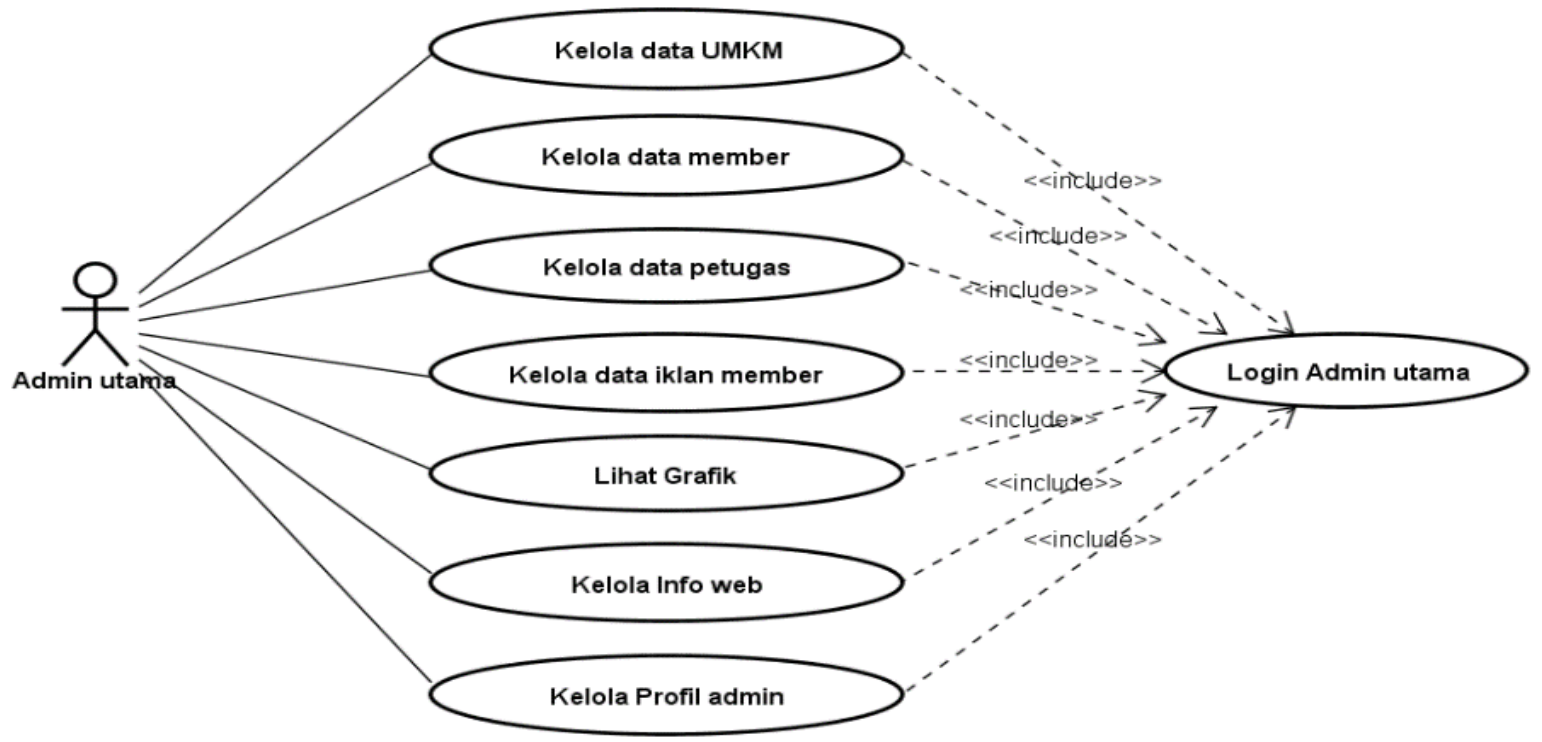

Gambar 3. Use case diagram Admin Utama

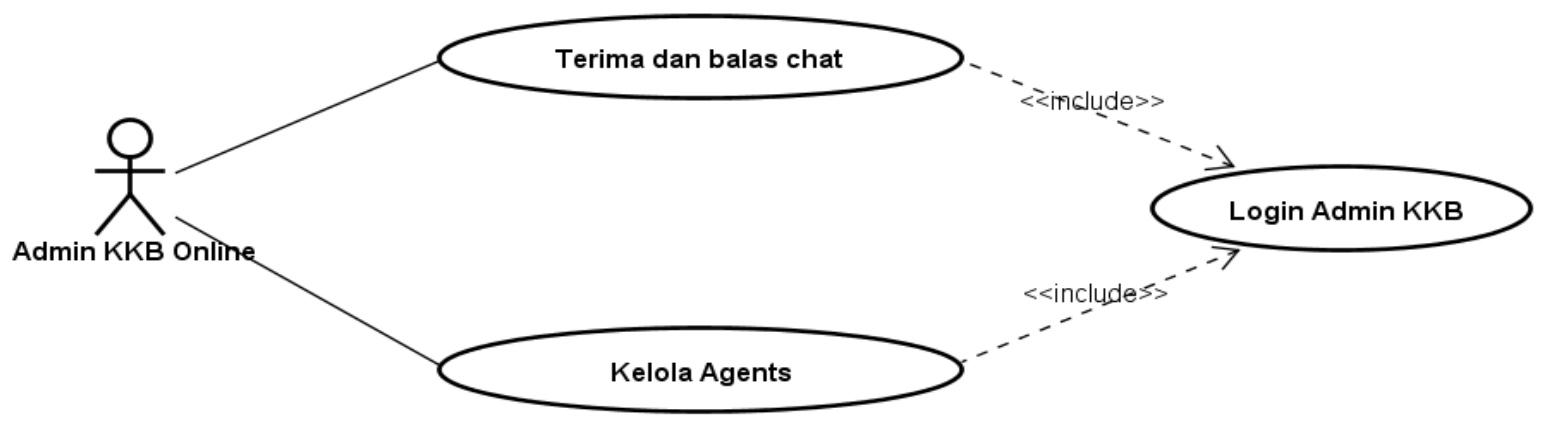

Gambar 4. Use case diagram Admin KKB Online 


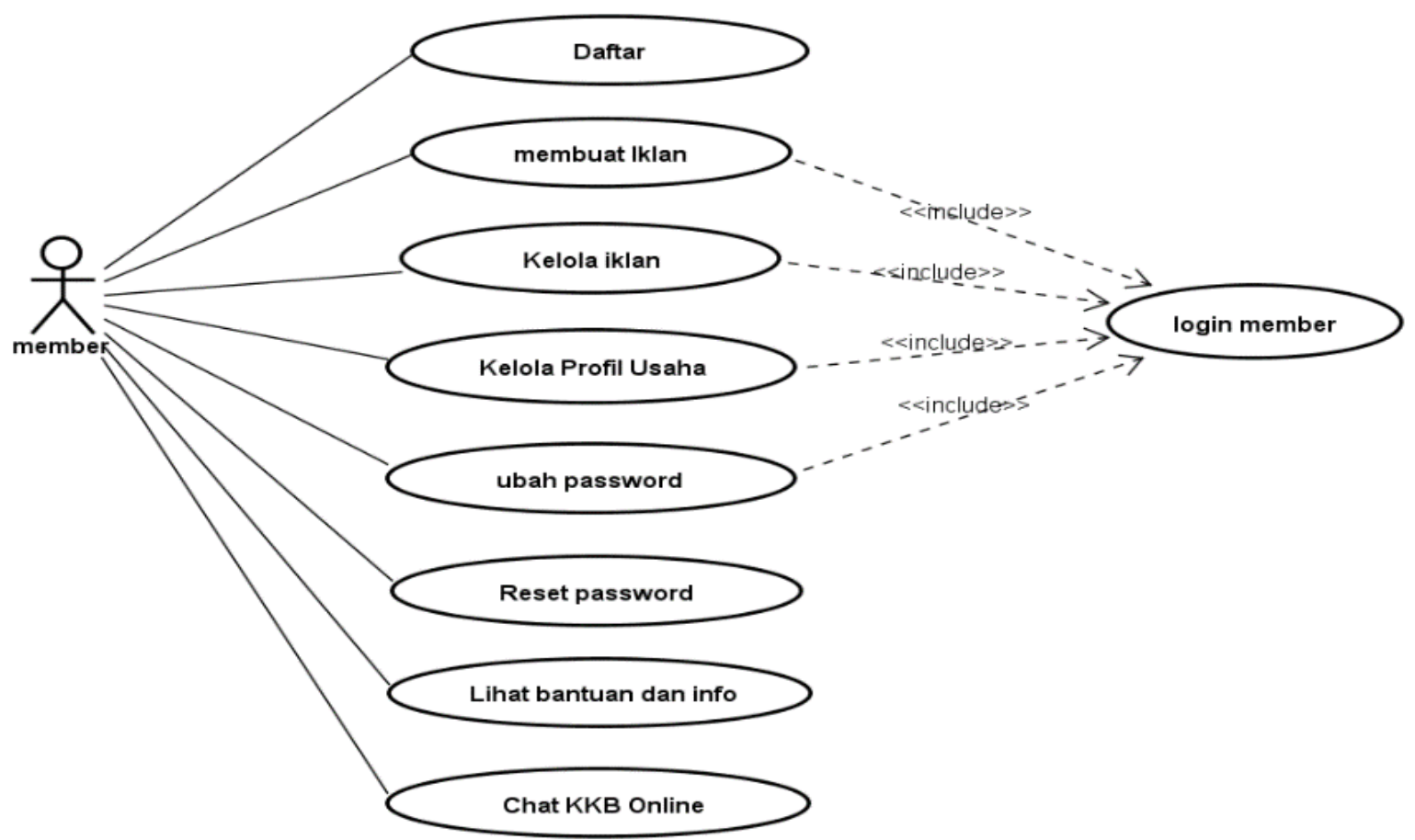

Gambar 5. Use case diagram Member

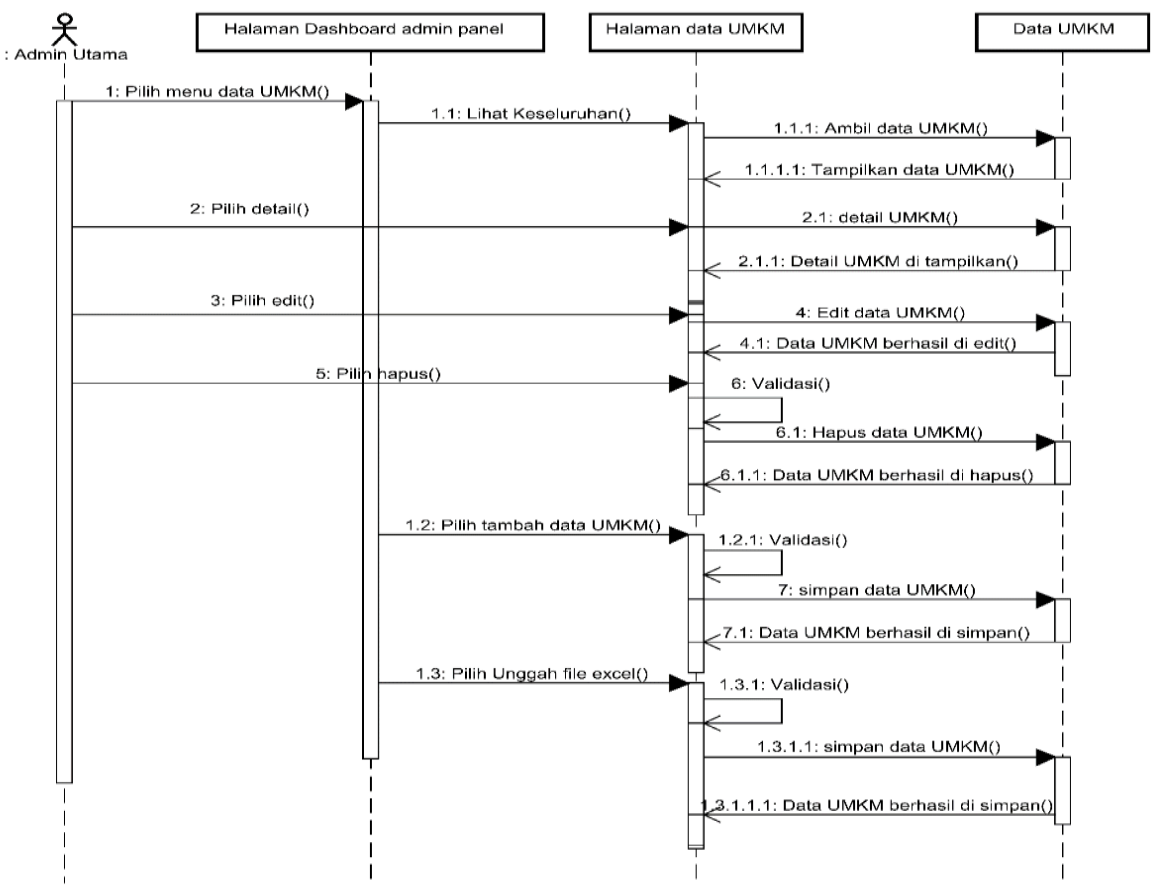

diagram kelola data UMKM

Gambar 6. Sequence 
Jurnal Ilmiah Rekayasa dan Manajemen Sistem Informasi, Vol. 6, No. 1, Februari 2020, Hal. 43-54 e-ISSN 2502-8995 p-ISSN 2460-8181

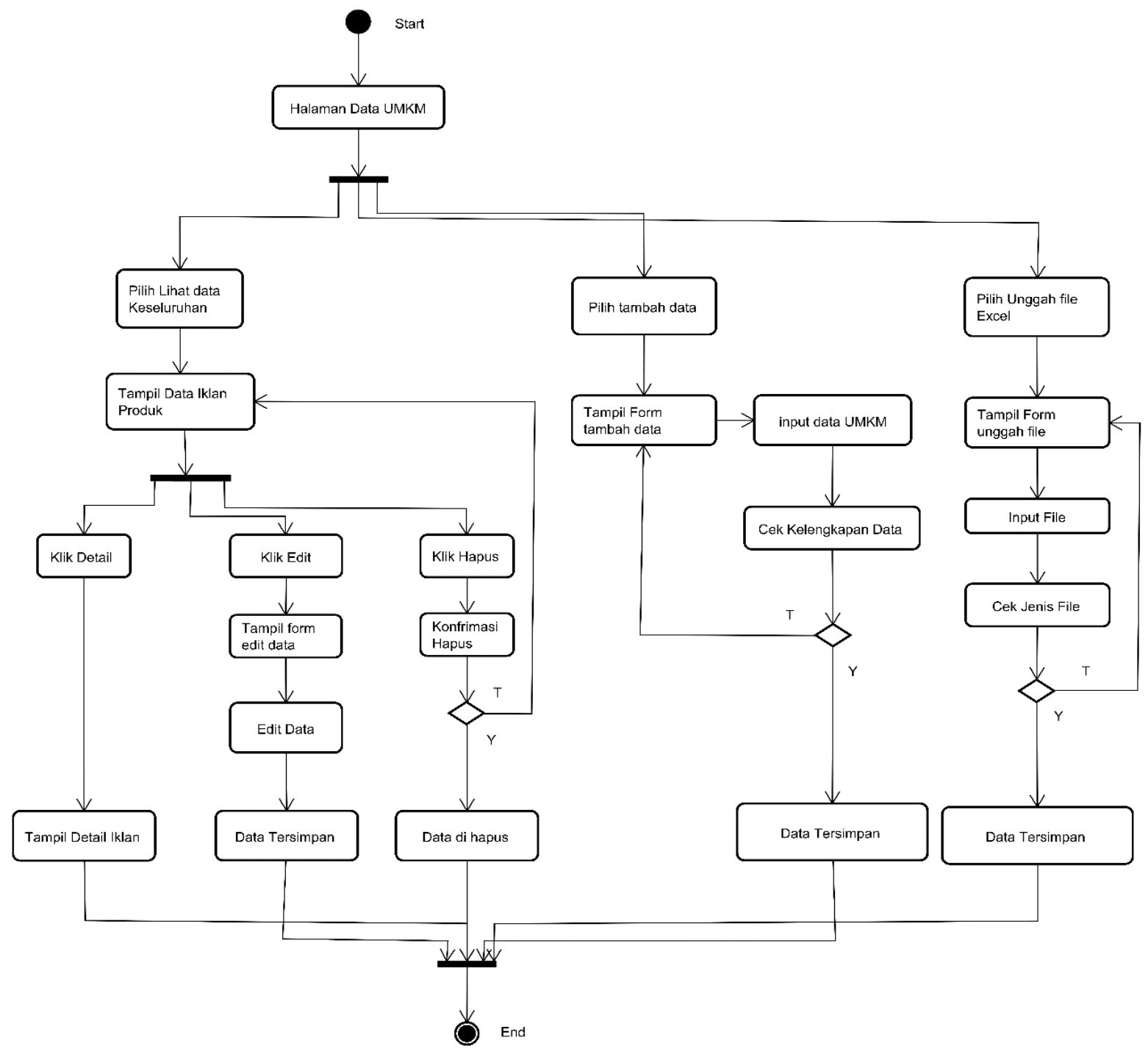

Gambar 7 Activity Diagram kelola data UMKM 


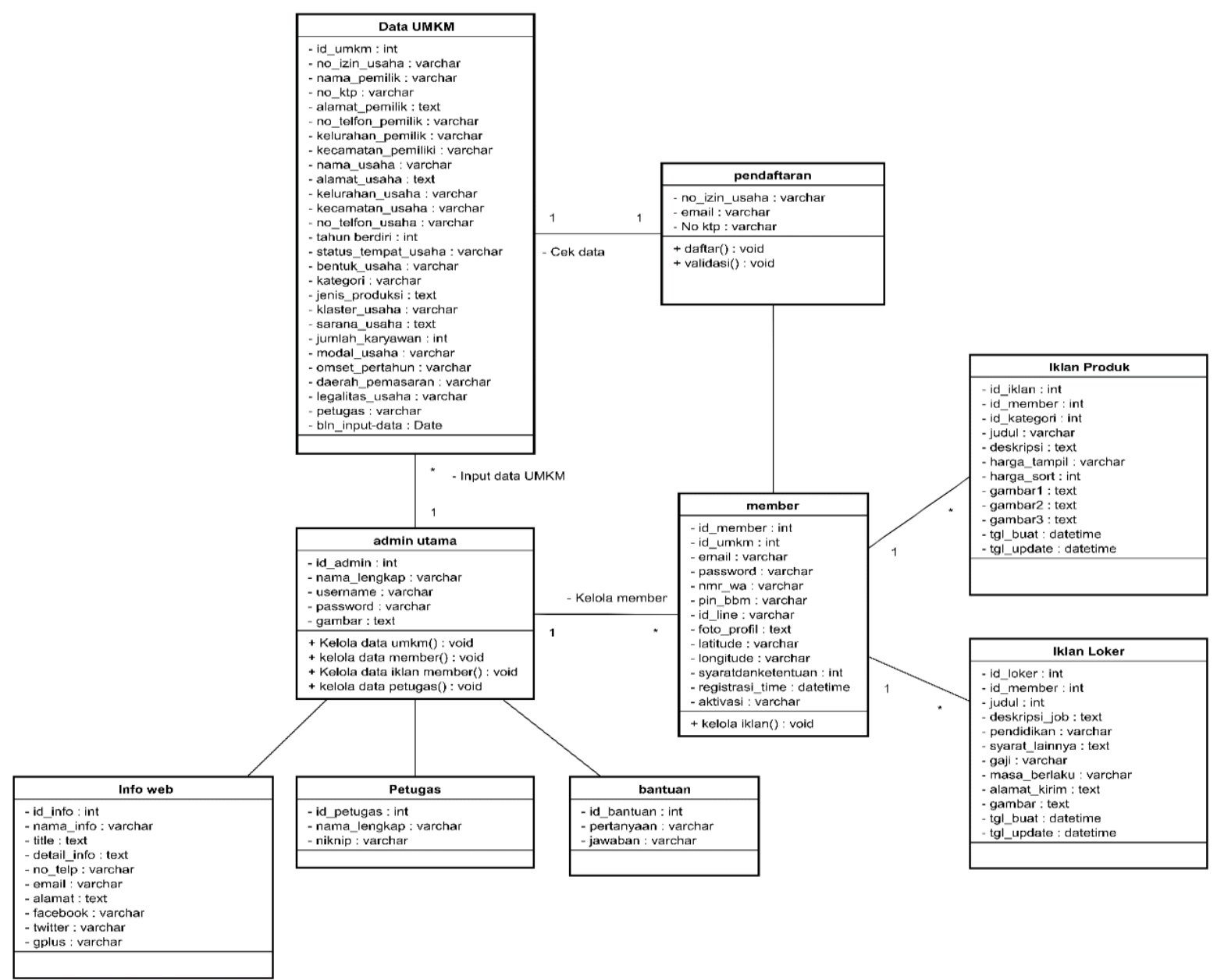

Gambar 8. Class Diagram

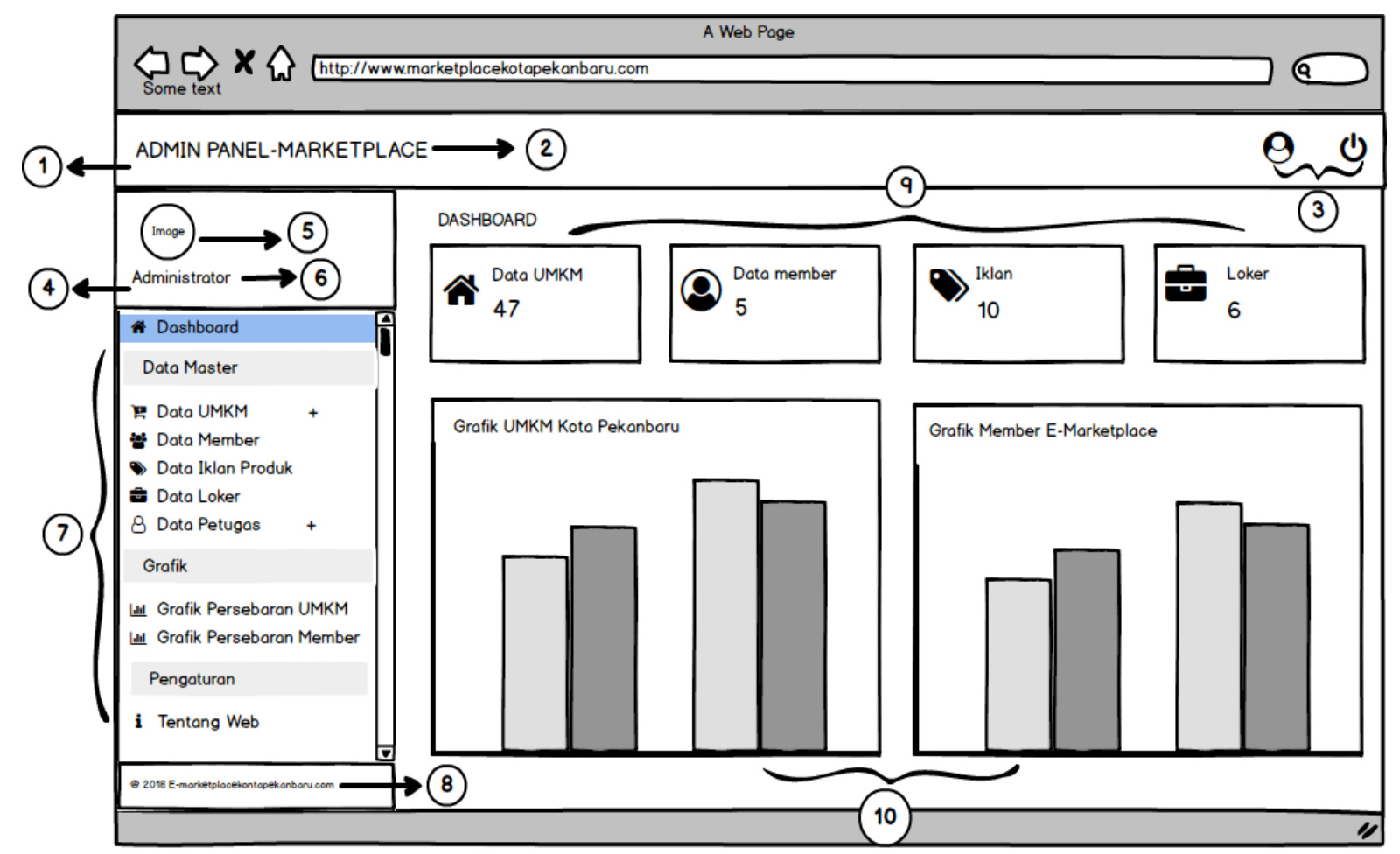

Gambar 9. Perancangan Halaman Dashboard Admin Panel e-Marketplace 
Jurnal Ilmiah Rekayasa dan Manajemen Sistem Informasi, Vol. 6, No. 1, Februari 2020, Hal. 43-54

e-ISSN 2502-8995 p-ISSN 2460-8181

\section{E. IMPLEMANTASI DAN PENGUJIAN \\ E.1. Implementasi}

Pada sistem e-Marketplace ini terdapat beberapa halaman yakni halaman Admin panel, Halaman Member, Halaman Web dan Halaman Admin KKB online masing-masing halaman memiliki hak aksesnya masing-masing.

Gambar 10 merupakan gambar halaman utama $e$-Marketplace yang terdiri dari menu-menu utama sistem yang disajikan dalam bentuk iconicon. Sedangkan Gambar 11 merupakan halaman dashboard dari sistem admin panel, dimana halaman ini menampilkan info-info umum tentang data yang terdapat di dalam admin panel sistem. Gambar 12 merupakan halaman kelola data UMKM dimana Admin Utama dapat menambah, memperbaharui, menghapus data UMKM. Untuk mendaftar sebagai member, Gambar 13 merupakan halaman daftar member di e-Marketplace. Sedangkan Gambar 14 merupakan halaman untuk lihat iklan yang ada pada $e$-Marketplace.
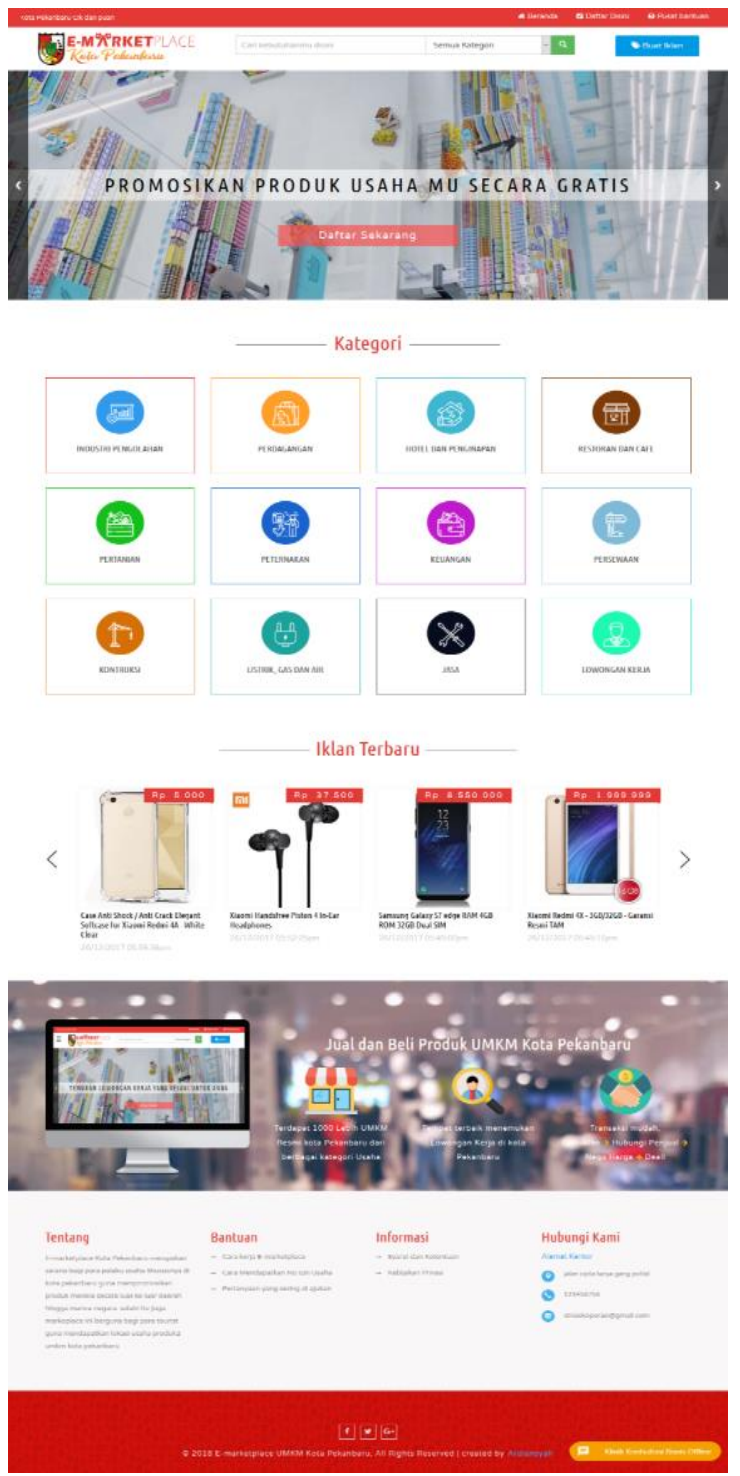

Gambar 10. Halaman Utama e-Marketplace

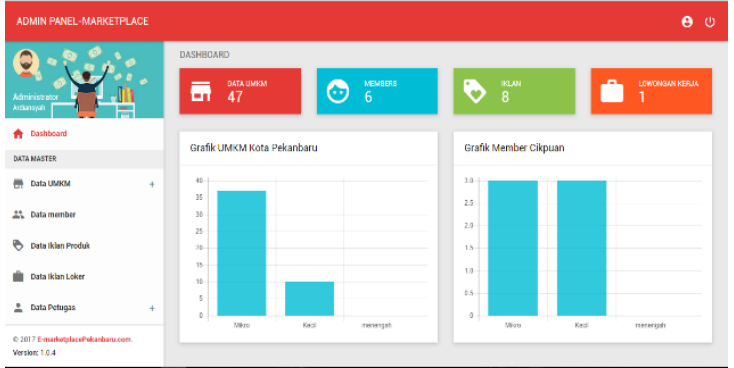

Gambar 11. Halaman Dashboard Admin Panel

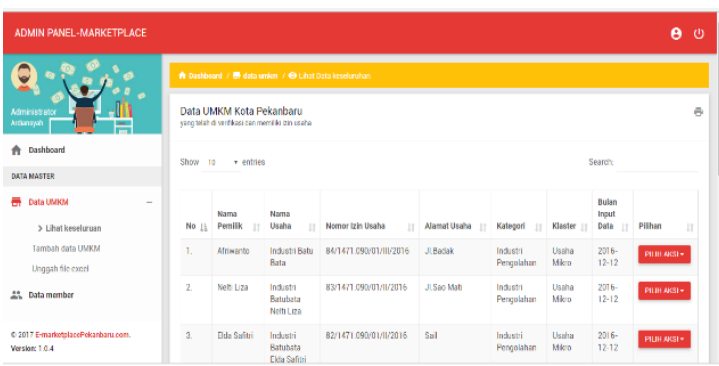

Gambar 12. Halaman Kelola data UMKM

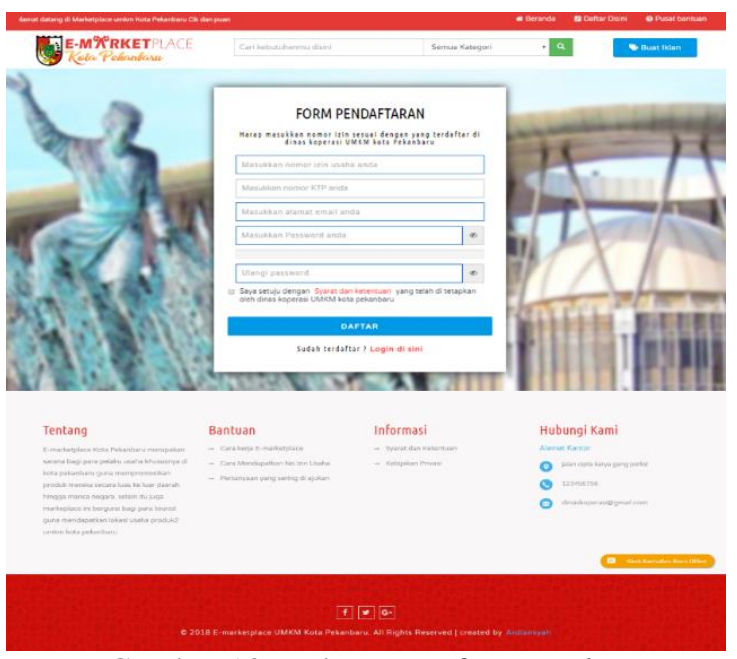

Gambar 13. Halaman Daftar Member

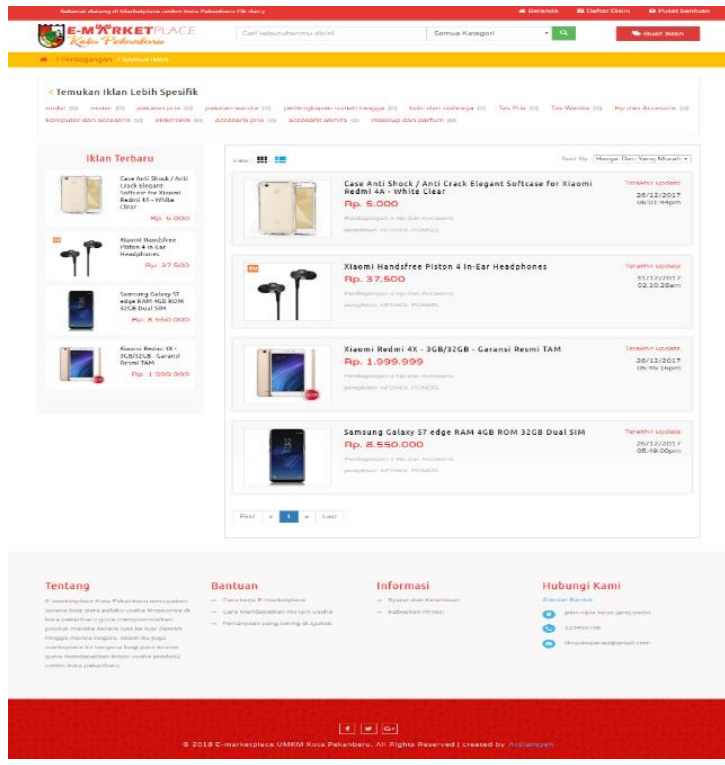

Gambar 14. Halaman Lihat Iklan 


\section{E.2. Pengujian}

Sebelum melakukan pengujian sistem menggunakan UAT, terlebih dahulu sistem diuji pada beberapa web browser untuk memastikan apakah sistem sudah berjalan dengan baik. Beberapa browser yang dilibatkan pada pengujian ini diantaranya Mozilla Firefox, Google Chrome, Opera, dan Microsoft Edge. Hasil yang diperoleh mendapatkan nilai rata-rata $100 \%$. Hal ini dapat disimpulkan bahwa sistem $e$-Marketplace tidak ada kendala yang ditemukan dari sisi disain yang ada pada fitur-fitur halaman dan secara fungsionalitas sistem. Untuk melihat hasil pengujian dengan menggunakan beberapa web browser dapat dilihat pada Tabel 2 Uji Web Broser.

Pengujian berikutnya dilakukan dengan menggunakan metode UAT. Berdasarkan Tabel 3 didapatkan hasil rata-rata $88,4 \%$ tingkat penerimaan sistem yang dilakukan pada pelaku usaha langsuung yang merupakan salah satu tipe aktor yang terlibat di sistem. Nilai rata-rata ini masih menunjukkan bahwa sistem masih dapat diterima dengan baik oleh pengguna Member. Sedangkan Tabel 4 merupakan hasil penilaian pengguna dari kalangan Masyarakat yang mendapatkan nilai rata-rata $82,6 \%$. Hal ini juga mengindikasikan bahwa sistem masih dapat diterima dengan baik oleh pengguna di kalangan masyarakat.

Tabel 2. Uji Web Browser

\begin{tabular}{cc}
\hline Browser & Tingkat Keberhasilan \\
\hline Mozilla Firefox & $100 \%$ \\
\hline Google Chrome & $100 \%$ \\
\hline Opera & $100 \%$ \\
\hline Microsoft Edge & $100 \%$ \\
\hline Rata-rata & $\mathbf{1 0 0 \%}$ \\
\hline
\end{tabular}

Tabel 3. Hasil UAT untuk Pelaku Usaha (Member)

\begin{tabular}{cc}
\hline User & Tingkat Penerimaan \\
\hline Pelaku Usaha 1 & $100 \%$ \\
\hline Pelaku Usaha 2 & $71,0 \%$ \\
\hline Pelaku Usaha 3 & $85,71 \%$ \\
\hline Pelaku Usaha 4 & $85,71 \%$ \\
\hline Pelaku Usaha 5 & $100 \%$ \\
\hline Rata-rata & $\mathbf{8 8 , 4 \%}$ \\
\hline
\end{tabular}

Tabel 4. Hasil UAT untuk pengguna Masyarakat

\begin{tabular}{cc}
\hline User & Tingkat Penerimaan \\
\hline Masyarakat 1 & $71,0 \%$ \\
\hline Masyarakat 2 & $85,71 \%$ \\
\hline Masyarakat 3 & $71,0 \%$ \\
\hline Masyarakat 4 & $100 \%$ \\
\hline masyarakat 5 & $85,71 \%$ \\
\hline Rata-rata & $\mathbf{8 2 , 6 \%}$ \\
\hline
\end{tabular}

\section{F. KESIMPULAN}

Berdasarkan hasil penelitian yang telah dilakukan dalam membangun sistem e-Marketplace
UMKM ini, maka dapat di tarik kesimpulan yaitu: (1) Berdasarkan hasil dari analisis biaya dan manfaat dengan menggunakan metode Payback Period dan Return of Investment (ROI) menunjukkan bahwa pembangunan sistem $e$ Marketplace ini layak untuk dikembangkan dan mampu memudahkan pihak dinas dalam mengelola data UMKM; (2) Bagi pelaku usaha, sistem ini mampu memudahkan dalam mempromosikan produk usaha mereka secara luas. Sistem juga mempermudah para pelaku dalam melakukan konsultasi dengan pihak dinas karena tidak perlu lagi datang ke dinas untuk melakukan konsultasi; (3) Dari hasil penujian yang telah dilakukan dengan menggunakan web browser bahwa fitur-fitur yang terdapat pada $e$-Marketplace dapat berjalan dengan baik karena tidak terdapat adanya kesalahan; (4) Hasil uji peneriamaan sistem dengan menggunakan UAT menyimpulkan bahwa tingkat penerimaan sistem masih dalam kategori dapat diterima oleh pengguna sistem.

\section{REFERENSI}

[1] UU 20 Tahun 2008 Tentang UMKM [Online] available www.bi.go.id/id/tentang-bi/uubi/Documents/UU20Tahun2008UMKM.pdf, diakses 23 Agsutus 2016.

[2] Bank Indonesia dan LPPI "Profil Bisnis Usaha Mikro, Kecil dan Menengah (UMKM)" [Online] Available https://www.bi.go.id/id /umkm/.../Profil\%20Bisnis\%20UMKM.pdf di akses 12 Januari 2018.

[3] Prasetyo, Eko. P. "Peran Usaha Mikro Kecil Dan Menengah (Umkm) Dalam Kebijakan Penanggulangan Kemiskinan Dan Pengangguran" AKMENIKA UPY, Vol. 2, 2008.

[4] Kodong, dkk. "Model Aplikasi E-market sebagai Sarana Promosi dan Tukar menukar Informasi antara Penjual dan Pembeli," Telematika Vol. 2, No. 2, hal. 75-84, 2012.

[5] Sadgotra, Y.W dan Erik, H.S. "Perancangan Online Marketplace Untuk Usaha kecil dan Menengah (UKM) di kabupaten Purworejo," Jurnal Ilmiah DASI Vol. 14, hal. 54-58, 2013

[6] Hartono, Jugiyanto. "Analisis dan desain sistem informasi pendekatan terstruktur teori dan praktik aplikasi bisnis". Andi, Yogyakarta: 1999.

[7] Zarnelly, dan Adelia, D. "Rancang Bangun Media Pelayanan Umum Desk Info Di Pengadilan Tinggi Agama Pekanbaru”. Jurnal Informatika. ISSN 2502-8995, Vol.14, No.1. Juni 2014.

[8] Ahsyar, Tengku Khairil. Sistem Informasi Sekolah Berbasis Web Pada Smk Labor 
Jurnal Ilmiah Rekayasa dan Manajemen Sistem Informasi, Vol. 6, No. 1, Februari 2020, Hal. 43-54 e-ISSN 2502-8995 p-ISSN 2460-8181

Pekanbaru. Diss. Universitas Islam Negeri

Sultan Syarif Kasim Riau, 2011. 